\title{
From Disease to Holiness: Religious-based health remedies of Italian folk medicine (XIX-XX century)
}

\author{
Nelide Romeo, Olivier Gallo and Giuseppe Tagarelli
}

\begin{abstract}
Background: The relationship between spirituality, religion and medicine has been recognized since antiquity. Despite large differences in their history, society, economy and cultures human communities shared a common belief that spirituality and religion played an important role in the healing of diseases.

Methods: The study of religious remedies used by Italian folk medicine in order to treat diseases was based on a review of literature sources compiled between the late nineteenth century and the early to mid twentieth century.

Results: This approach lead to the unearthing of heterogeneous healing methods that have been divided into different categories: Saints, Pilgrimages, Holy Water/Blessed Oil, Blessings, Religious Objects, Contact, Signs, Formulas and The Religious Calendar.

Some of these practices, partly still performed in Italy, are a part of the landscape of the official Catholic Church, others come out of a process of syncretism between the Catholic Religion, the magic world and pre-Christian rituals.

Conclusions: The vastus corpus of religious remedies, highlighted in the present work, shows the need for spirituality of the sick and represent a symbolic framework, that works as a filter, mediates, containing the pain that constantly fills everyone's lives in remote ages even in the third millennium. All of this confirms how important the health-workers know and interpret these existential needs from anthropological and psychological points of view.
\end{abstract}

Keywords: Folk medicine, Religion, Spirituality, Coping

\section{Introduction}

The relationship between spirituality, religion and medicine has been recognized since antiquity in human communities living in different geographic areas of the world. Despite large differences in their history, society and economy, cultures from North and South America, The Far East and The Middle East, Africa and The Mediterranean area, shared a common belief that spirituality and religion played an important role in the healing of diseases. Afterwards, above all in Eastern cultures, spiritual and religious components have always been believed to be important factors in maintaining health. Instead, in Western cultures, above all after the Renaissance and the Late Enlightenment, spiritual and religious dimensions have diverged from medicine [1].

Nowadays, bio-medical research around the world, enriched by the contribution of other disciplines such as psychology and anthropology, shows growing interest in

\footnotetext{
* Correspondence: g.tagarelli@isn.cnr.it

Istituto di Scienze Neurologiche-CNR, Mangone (CS), Italy
}

the relationship between spirituality, religion and health $[2,3]$. In recent years, scientific literature highlighted that spirituality/religiosity can improve recovery from illnesses such as cancer [4], mental disorders [5], cardiovascular diseases, rheumatoid arthritis and head injuries [6].

At the same time it has developed an interesting debate on the definition of spirituality and religiosity. Some authors use the terms spirituality and religiosity as synonyms asserting that the two concepts have common matrix in rites and rituals and so cannot be separated. Others assert that spirituality is associated with finding meaning and purpose in life, transcendence beyond the physical body, and/or experiencing a sense of connectedness with self, others, nature, and/or a power greater than oneself. While, religiosity is associated with human expression of the rites and rituals of a particular faith tradition [7].

Moreover, spirituality/religiosity and culture are inextricably woven together [8]. The rituals, symbols and myths tied to religion can be interpreted as ways of making sense 
of the world [9]. According to Tarakeshwar, Stanton and Pargament [10], some people who believe in a sacred power view the world through the lens of mythic vocabularies and regulate their lives according to the models and injunctions set forth in their religious traditions.

For all the reasons set out above, cultural competency has become a fashionable term for clinicians too. The clinician can empathize with the lived experience of the patient's illness, and try to understand the illness as the patient understands, feels, perceives and responds to it. But the large claims about the value of cultural competence for the art of professional care-giving around the world are simply non supported by robust evaluation research showing that systematic attention to culture really improves clinically service. Culture is often made synonymous with ethnicity, nationality and language, so patients of a certain ethnicity are assumed to have a core set of beliefs about illness owing to fixed ethnic traits [11]. Anthropologists, for example, have well documented these kinds of healthrelated beliefs for several of the ethnic groups in the United States [12]. Cultural differences, however, are not always accompanied by obvious markers such as language and ethnicity. There are people within our own modern society that adopt distinctive values, beliefs and rules for behaviour even if they have the same linguistic, ethnic, religious traits as their fellow-countrymen [13].

An example of this is represented by Italy, which is still today characterized by widespread affiliation to Catholicism (more than $80 \%$ of the population), despite the increase in religious pluralism and undisputed secularization in the customs of population [14]. In Italy, however, to face the moment of illness part of the Italian population still carry out various manifestations of "unofficial" catholic religious expression $[15,16]$, so like trust in magician to heal ( $4 \%$ of the population) [17].

The present work aims to unearth the religious remedies used by Italian folk medicine to heal diseases, between the late nineteenth century and the early to mid-twentieth century. The dual propose of this study is to explore how an historical anthropological perspective can provide a different lens through which to explain "unofficial" catholic religious remedies to heal diseases partly still performed in Italy and to interpret their symbolic representations and spiritual meanings.

\section{Materials and methods}

The study of religious remedies used by Italian folk medicine in order to treat diseases was based on a review of literature sources compiled between the late nineteenth century and the early to mid twentieth century.

The literature sources were identified from the online catalogue of the National Library Service of the Italian libraries network, by checking up the following key words: "folk medicine", "usages and customs", "folk traditions" and "folk remedies". The methodology used has led to the consultation of ninety-seven sources (books and journal articles), compiled by anthropologists, physicians, ethnographers, folklorists, and scholars of local history between the late nineteenth century and the early to mid twentieth century.

In Italy, the beginning of this interval represents the period in which the study of folk traditions, including the collection of folk remedies for the cure of diseases, was created and dispersed with well-codified methodological bases [18]. While at the end of the 1950s there was the abandonment of the countryside to the cities so that, for the first time, the Italian population employed in industry exceeded that in agriculture [19]. This phenomenon contributed to the so-called "economic boom" and to the social and cultural transformation of Italy, which went from a predominantly agricultural society to a modern society [20].

Diseases and relative religious remedies used by Italian folk medicine for their care, have been grouped according to International Classification of Diseases (ICD, version 10) endorsed by World Health Organization [21].

\section{Results}

The sources consulted in this study highlighted a vastus corpus of religious remedies used to heal various diseases. These numerous sources showed how the interaction between religion and folk medicine has produced at the same time methods that have become part of official religious rites, like the cult of Saints, the use of Holy Water and Blessed Oil, and remedies that highlighted a strong influence between the Catholic religion, magic and pre-Christian practices.

The remedies have been divided into nine different categories: Saints, Pilgrimages, Holy Water/Blessed Oil, Blessings, Religious Objects (Table 1), Contact, Signs, Formulas and The Religious Calendar (Table 2).

Therefore, because of the impossibility to explain every single remedy, are described, for every category, some remedies that largely favour the comprehension of their use in Italian Folk medicine.

\section{Saints}

To heal themselves from diseases, people entrusted The Holy Spirit, God, Jesus, Mary and the Saints with prayers or acts of devotion (Table 1). The Saint is invoked to heal a specific disease which was chosen because during its martyrdom they were inflicted in the same part of the body that the people have asked to heal [22]. Saint Valentino and Saint Donato, killed by decapitation, were considered the protectors of epileptics [23-26]; Saint Lorenzo, burnt alive, was considered the curer of burns [27-29]; Saint Apollonia to whom, during martyrdom, had her teeth extracted is prayed to by sufferers of 
Table 1 Invocation of Saints, Pilgrimages to sacred places, use of Holy Water/Blessed Oil, Blessings and Sacred Objects used to

\section{cure disease}

\begin{tabular}{|c|c|}
\hline Diseases & Saints \\
\hline \multicolumn{2}{|c|}{$\begin{array}{l}\text { Certain infectious and } \\
\text { parasitic diseases }\end{array}$} \\
\hline Antrax & Saint Sebastiano [24]. \\
\hline Cholera & $\begin{array}{l}\text { Vergine del Carmine; Saint } \\
\text { Gregorio [86]. Saint Rosalia } \\
\text { [28]. Saint Gaetano [32]. }\end{array}$ \\
\hline Epidemics & Saint Marta [32]. \\
\hline Erysipelas & $\begin{array}{l}\text { Saint John; Saint Agostino } \\
\text { [28]. Saint Irene; Saint } \\
\text { Elisabetta [32]. }\end{array}$ \\
\hline
\end{tabular}

Fever

Helminthiasis

Herpes

Malaria

\section{Saint Antonio Abate [23].}

Beato Riziero [31]. Saint

Domenico; Saint Floriano

[23].

$\begin{array}{ll}\text { Plague } & \text { Saint Rocco [23, 25, 29, 32, } \\ & 46,86] . \text { Saint Osvaldo [23]. } \\ \text { Rabies } & \text { Saint Bellino [36]. Saint } \\ & \text { Domenico da Cucullo [32]. }\end{array}$

Scabies

Smallpox

Tinea

Tuberculosis

Typhus

Warts
Saint Bonosa [32].

Saint Galicano [32].

Saint Giacinto [30]. Saint Teresa [29].
Pilgrimages

Holy Water Blessed Oil

Blessings

Religious Objects

Bless the part [45].

Wear a scapular [38].

Bless the sufferer [46]

Three chapels (Basilicata) [37]. Church of Madonna delle Febbri (Sicily) [28]. Altars of Madonna delle Febbri (Calabria) [87].

delle Febbri (Calabria) [87].
Church of Saint Egidio (Abruzzi)

Church of Saint Egidio (Abruzzi)
where it hangs a pebble behind the front door [24].

Church of Saint Domenico

(Abruzzi) [30]. Church of Saint

Vito (Basilicata) [37]. Church of

Saint Vito (Sicily) where the

sufferer had to exit from another

door and not the one they

entered in: Church of Saint Vito

(Sicily) [28]. Church of Saint

Bellino (Veneto) [25].

Holy Water [28].

Bless the sufferer [28].

Bless the sick [88]

Wear a scapular [23]

Carry in the pocket Saint

Giacomo of Compostela's Agnus Dei [32].

Wear Saint Vito's rope [28]. Put

Saint Domenico, Saint Stefano,

Saint Benigno and Saint Bellino's

key on $[38,43,46,47]$. Put Papa

Leone's epistle on [89].
Church of Madonna of Saint Agostino (Latium) [32]. 
Table 1 Invocation of Saints, Pilgrimages to sacred places, use of Holy Water/Blessed Oil, Blessings and Sacred Objects used to cure disease (Continued)

\begin{tabular}{|c|c|c|c|c|c|}
\hline \multicolumn{6}{|c|}{$\begin{array}{l}\text { Diseases of the blood } \\
\text { and blood-forming } \\
\text { organs and certain } \\
\text { disorders involving the } \\
\text { immune mechanism }\end{array}$} \\
\hline \multicolumn{4}{|l|}{ Blood Diseases } & \multicolumn{2}{|l|}{$\begin{array}{l}\text { Wear a necklace with a small- } \\
\text { blessed sack [90]. }\end{array}$} \\
\hline \multicolumn{6}{|c|}{$\begin{array}{l}\text { Endocrine, nutritional } \\
\text { and metabolic diseases }\end{array}$} \\
\hline \multicolumn{2}{|l|}{ Malnutrition } & & & \multicolumn{2}{|l|}{ Bless the sick [24]. } \\
\hline \multicolumn{6}{|c|}{$\begin{array}{l}\text { Mental and } \\
\text { behavioural disorders }\end{array}$} \\
\hline \multicolumn{2}{|l|}{ Fear } & $\begin{array}{l}\text { Church of Saint Vito (Sicily) } \\
\text { where the sufferer had to exit } \\
\text { from another door and not the } \\
\text { one they entered in [28]. }\end{array}$ & & \multicolumn{2}{|l|}{$\begin{array}{l}\text { Bless the sick after reading the } \\
\text { Gospel [91]. }\end{array}$} \\
\hline \multicolumn{2}{|l|}{ Hysteria } & $\begin{array}{l}\text { Sanctuary of Canoscio (Umbria) } \\
\text { [30]. Church of Saint Gregorio } \\
\text { (Abruzzi) [38]. }\end{array}$ & & \multicolumn{2}{|l|}{$\begin{array}{l}\text { Covering the sufferer with the } \\
\text { smoke of incense, blessed olive } \\
\text { leaves and salt [92]. }\end{array}$} \\
\hline Drunkenness & \multicolumn{5}{|l|}{$\begin{array}{l}\text { Patriarca Noè [23]. Saint } \\
\text { Quintino [29]. }\end{array}$} \\
\hline Madness & $\begin{array}{l}\text { Saint Maturino; Saint } \\
\text { Aventino [32]. }\end{array}$ & \multicolumn{2}{|l|}{$\begin{array}{l}\text { Sanctuary of Saint Ubaldo } \\
\text { (Umbria) [30]. Church of Saint } \\
\text { Vito (Sicily); Church of Saint } \\
\text { Filippo (Sicily) [28]. }\end{array}$} & \multicolumn{2}{|l|}{ Wear a blessed shirt [35]. } \\
\hline Mutism & \multirow{2}{*}{\multicolumn{5}{|c|}{ Saint Zaccaria [32]. }} \\
\hline $\begin{array}{l}\text { Diseases of the } \\
\text { nervous system }\end{array}$ & & & & & \\
\hline \multicolumn{2}{|l|}{ Chorea } & \multicolumn{4}{|l|}{$\begin{array}{l}\text { Church of Saint Filippo d'Agira } \\
\text { (Sicily); Church of Saint Leonardo } \\
\text { (Sicily) where the sick walked } \\
\text { three times around the church; } \\
\text { Church of Saint Vito (Sicily); } \\
\text { Church of Greci (Sicily); Church of } \\
\text { Madonna della Nunziata (Sicily) } \\
\text { [28]. }\end{array}$} \\
\hline Epilepsy & $\begin{array}{l}\text { Three Kings [30, 45, 93]. Saint } \\
\text { Andrea Avellino; Saint John; } \\
\text { Saint Vincenzo Ferrer [28]. } \\
\text { Saint Donato [24, 26]. Saint } \\
\text { Valentino [23]. Saint }\end{array}$ & $\begin{array}{l}\text { Sanctuary of Canoscio (Umbria) } \\
\text { [30]. Church of Saint Valentino } \\
\text { (Veneto) [25]. Church of Saint } \\
\text { Geminiano (Emilia Romagna) } \\
\text { where the sufferer went under } \\
\text { the crypt of Saint [36]. Church of }\end{array}$ & Holy Water [28, 32]. & $\begin{array}{l}\text { Wear a blessed shirt [35]. Drop } \\
\text { on the head some blessed wax } \\
\text { drips [30]. Tie at the wrists and } \\
\text { the ankles some blessed leaves } \\
\text { [64]. Covering the sufferer with }\end{array}$ & $\begin{array}{l}\text { Put Saint Domenico da Cucullo's } \\
\text { medal and keys on; put Holy } \\
\text { Spirit's coin on; brand the skin } \\
\text { with Saint Domenico's iron or } \\
\text { key [30]. Wear a necklace with } \\
\text { Saint Donato's silver medal [26]. }\end{array}$ \\
\hline
\end{tabular}


Table 1 Invocation of Saints, Pilgrimages to sacred places, use of Holy Water/Blessed Oil, Blessings and Sacred Objects used to cure disease (Continued)

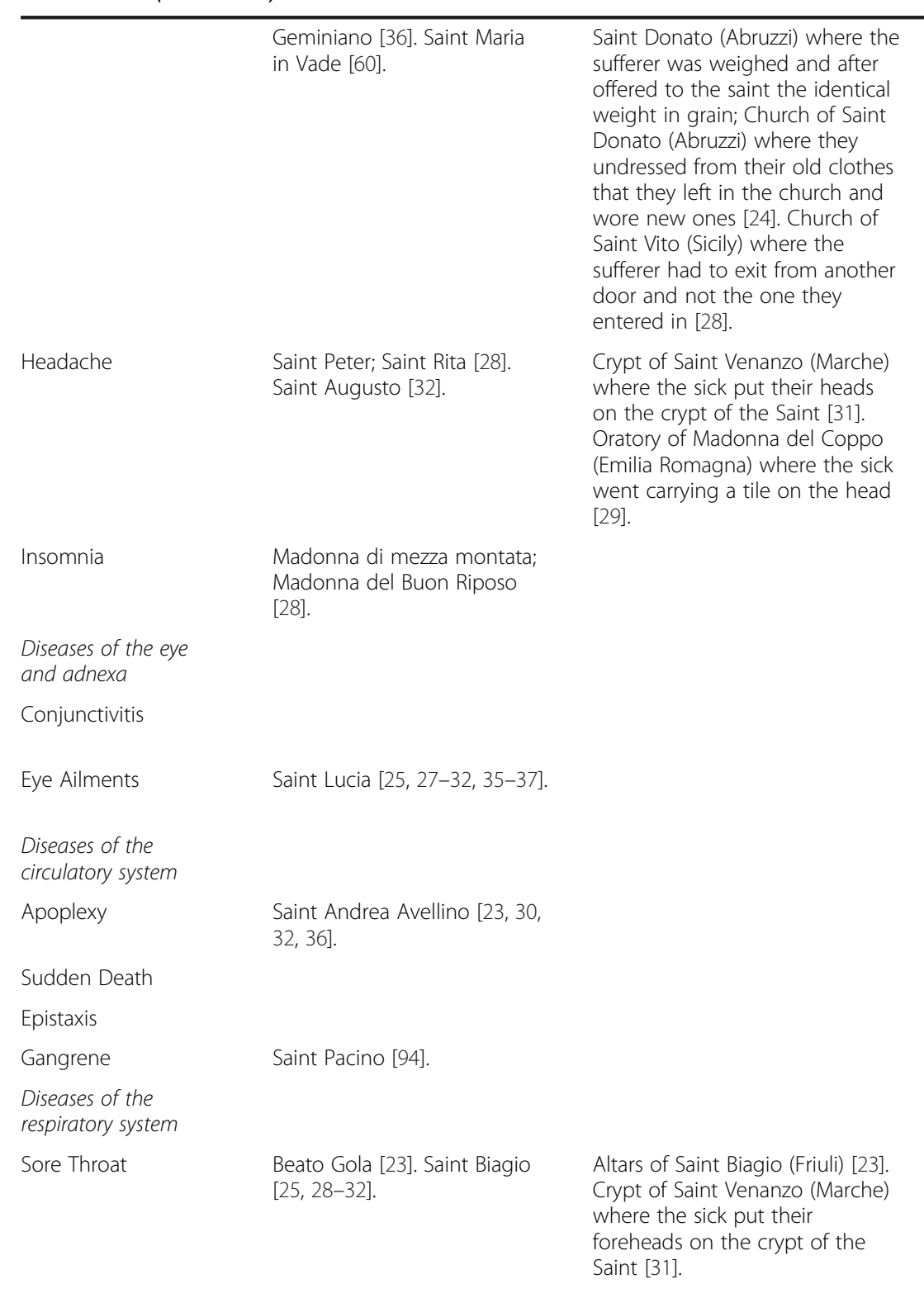

$\begin{array}{ll}\text { the smoke of incense, blessed } & \text { Put Saint Valentino's key on [23, } \\ \text { olive leaves and salt [92]. } & 46,47] \text {. Wear a necklace with a } \\ & \text { silver blessed key; put Saint } \\ & \text { Margherita's little cross on [28]. } \\ & \text { Put Saint Elena's and Saint } \\ & \text { Costantino's coins on [23]. }\end{array}$

Holy Water [23]. Bless the head [28].

Put on a lead ring bought in the
church of Saint Peter (Sicily) [28].
Tie Saint Augusta's ribbons
around the head [46].

Tie Saint Augusta's ribbons
around the head [46].

Rubbing a leaf of a blessed palm on the part [24].

Holy Water $[28,30$ 42, 43].

Blessed Oil [37].

Bless the throat $[23,31]$. Wear a blessed shirt [46]. Eat blessed apples [23]. Put the neck between two blessed candles [35].
Put Saint Andrea Avellino's medal on [30].

Put Papa Leone's epistle on [89]. Put Papa Leone's epistle on [89].

Wear Saint Biagio's necklace [28]. 
Table 1 Invocation of Saints, Pilgrimages to sacred places, use of Holy Water/Blessed Oil, Blessings and Sacred Objects used to cure disease (Continued)

\begin{tabular}{|c|c|c|c|c|c|}
\hline Tussis & $\begin{array}{l}\text { Saint Tossano [31]. Madonna } \\
\text { della Tosse [46]. }\end{array}$ & $\begin{array}{l}\text { Church of Madonna della Tosse } \\
\text { (Tuscany), coming back from } \\
\text { another road and not that they } \\
\text { travelled during the outward } \\
\text { journey [90]. }\end{array}$ & & & \\
\hline \multicolumn{6}{|l|}{$\begin{array}{l}\text { Diseases of the } \\
\text { digestive system }\end{array}$} \\
\hline Hernia & $\begin{array}{l}\text { Saint Alfio; Saint Bartolomeo, } \\
\text { Saint Giacomo; Saint Corrado } \\
\text { [28]. Saint Cataldo [36]. Saint } \\
\text { Pantaleone [24]. }\end{array}$ & $\begin{array}{l}\text { Saint Calogero's procession } \\
\text { (Sicily) [28]. Church of Madonna } \\
\text { del Monte (Apulia) where the } \\
\text { sufferer had to exit from another } \\
\text { door and not the one they } \\
\text { entered in [40]. }\end{array}$ & & & \\
\hline Hepatitis & $\begin{array}{l}\text { Madonna del giallume [24]. } \\
\text { Jesus; Saint Francesco di } \\
\text { Paola [28]. }\end{array}$ & & & $\begin{array}{l}\text { Drink a concoction made with } \\
\text { an Easter candle, Mary's candle, } \\
\text { hairs and nails of the sick [95]. }\end{array}$ & \\
\hline Stomachache & $\begin{array}{l}\text { Saint Albertino; Saint Santo } \\
\text { [30]. Saint Timoteo [36]. Saint } \\
\text { Erasmo [32]. }\end{array}$ & & & $\begin{array}{l}\text { Passing a light blessed candle in } \\
\text { a glass over the part [96]. Light a } \\
\text { blessed candle and place on a } \\
\text { coin on the part of the body, } \\
\text { then these are covered with an } \\
\text { upturned glass [31]. }\end{array}$ & \\
\hline Stomatitis & & & Holy Water [38]. & & \\
\hline Toothache & $\begin{array}{l}\text { Saint Apollonia [23, 25, 27, 28, } \\
\text { 30-33]. }\end{array}$ & $\begin{array}{l}\text { Church of Saint Apollonia } \\
\text { (Sicily) [28]. }\end{array}$ & & & $\begin{array}{l}\text { Touch the part with Saint } \\
\text { Domenico da Cucullo's iron [38]. }\end{array}$ \\
\hline \multicolumn{6}{|c|}{$\begin{array}{l}\text { Diseases of the skin } \\
\text { and subcutaneous } \\
\text { tissue }\end{array}$} \\
\hline Baldness & Saint Peter [28]. & & & & \\
\hline Boils & & & & $\begin{array}{l}\text { Pierce the boil with the tip of a } \\
\text { leaf of a blessed palm [24]. }\end{array}$ & \\
\hline Hyperhidrosis & & & Holy Water [28]. & & \\
\hline Milk Crust & Saint Silvestro [46]. & Altar of Saint Agnese (Friuli) [23]. & & & \\
\hline \multicolumn{6}{|c|}{$\begin{array}{l}\text { Diseases of the } \\
\text { musculoskeletal system } \\
\text { and connective tissue }\end{array}$} \\
\hline Arthritis & $\begin{array}{l}\text { Saint Peter and Saint Paolo } \\
\text { [31]. Saint Ventura [30]. Saint } \\
\text { Mauro Abate [30, 32]. }\end{array}$ & $\begin{array}{l}\text { Church of Saint Ventura (Umbria) } \\
\text { where the sick lies down [30]. }\end{array}$ & Blessed Oil [30]. & $\begin{array}{l}\text { Drop on the part some blessed } \\
\text { wax drips [30]. }\end{array}$ & \\
\hline Dislocations & & & & $\begin{array}{l}\text { Drop on the part some blessed } \\
\text { wax drips [30]. }\end{array}$ & \\
\hline
\end{tabular}

Diseases of the skin

tissue

Baldness

Hyperhidrosis

\section{Milk Crust}

Diseases of the

[31]. Saint Ventura [30]. Saint

[31]. Saint Ventura [30].
Mauro Abate [30, 32].
Saint Giacomo; Saint Corrado

[28]. Saint Cataldo [36]. Saint

Madonna del giallume [24]

Paola [28].

[30]. Saint Timoteo [36]. Sain

rasmo [32]. 
Table 1 Invocation of Saints, Pilgrimages to sacred places, use of Holy Water/Blessed Oil, Blessings and Sacred Objects used to cure disease (Continued)

\begin{tabular}{|c|c|c|}
\hline Gout & Saint Tommaso [32]. & $\begin{array}{l}\text { Church of Saint Ventura (Umbria) } \\
\text { where the sick lies down [30]. }\end{array}$ \\
\hline
\end{tabular}

Sciatica

Sprains

Diseases of the

genitourinary system

Infertility

Saint Rita [35]

To regularize

Menstruations

Metrorrhagia

Renal Colics

Pregnancy, childbirth and the puerperium

To favour Birth

Saint Anna $[25,29-32,38,90$

Saint Libero [46]. Beato Netta

[63]. Madonna dei sette

dolori; Saint Torello; Madonna

delle Grazie; Saint Francesco

di Paola [30]. Saint Rita; Saint

Leonardo; Saint Nicola; Saint

Antonio da Padova [38]. Sain Teodoro [32]

Breast Ailments

Saint Agata [23-25, 28]. Saint Joseph [28].

Puerperal fevers

To favour the secretion of Maternal Milk

Saint Martino [30]. Saint Agata [27, 30]. Saint Lena

[31].

\section{where the sick lies down [30].}

\section{Bless the part [45].}

Light a blessed candle and place

and cover with an

upturned glass [31].

Holy Water [30].

Covering the sufferer with the smoke of incense, blessed olive leaves, crab's eyes and salt [92].

Church of Madonna della Catena (Sicily) [28].

Church near Col San Martino (Veneto) [46]. Church of Saint

Teodoro (Latium) [32].

Bless the tummy [32]. Covering the woman in labour with the smoke of blessed olive leaves, blessed candles, sacred images, crab's eyes, salt, chicken feathers and hairs of the husband $[46,92]$.
Covering the woman in labour with the smoke of incense, blessed olive leaves, crab's eyes and salt [92].

Eat blessed food [30].
Gird the loins with Saint Francesco's rope; resting a Crucifix on the lower stomach [46]. Put Papa Leone's epistle on [89]. Put next to the bed Saint'Anna's or Madonna's rose $[27,45,47,49]$. Wear a necklace with Saint Torello's medal [30].

Put Rosary on [28].

Injury, poisoning and

certain other

consequences of

external causes 
Table 1 Invocation of Saints, Pilgrimages to sacred places, use of Holy Water/Blessed Oil, Blessings and Sacred Objects used to cure disease (Continued)

\begin{tabular}{|c|c|c|c|c|c|}
\hline Snake Bites & & & & & $\begin{array}{l}\text { Brand the skin with Saint } \\
\text { Domenico da Cucullo's iron [24] }\end{array}$ \\
\hline Venomous Bites & $\begin{array}{l}\text { Saint Domenico da Cucullo } \\
\text { [23, 31, 32]. Saint Giobbe [31]. } \\
\text { Saint Paolo [51]. Saint } \\
\text { Margherita [30]. }\end{array}$ & & & & Put Papa Leone's epistle on [89]. \\
\hline Burns & Saint Lorenzo [27-29] & & & & \\
\hline Contusions & & & & $\begin{array}{l}\text { Covering the sufferer with the } \\
\text { smoke of a blessed candle [46]. }\end{array}$ & \\
\hline Cripplings & Saint Eutropio [32]. & & & & \\
\hline Fractures & Saint Mauro [29]. & & & & \\
\hline Wounds & Saint Paolo [25]. & & & Apply blessed fat [31]. & \\
\hline \multicolumn{6}{|l|}{$\begin{array}{l}\text { External causes of } \\
\text { morbidity and } \\
\text { mortality }\end{array}$} \\
\hline Drowning & Saint Placido [36]. & & & & \\
\hline Falls & $\begin{array}{l}\text { Saint Venanzo [31]. Saint } \\
\text { Antonio di Padova [32]. Saint } \\
\text { Emarcora [23]. }\end{array}$ & & & & $\begin{array}{l}\text { Put Saint Giorgio and Saint } \\
\text { Venanzio's medal on }[23,30] .\end{array}$ \\
\hline \multicolumn{6}{|l|}{ Miscellanea } \\
\hline All Diseases & $\begin{array}{l}\text { Saint Antonio da Padova [29, } \\
\text { 35]. Saint Liberata [29]. Saint } \\
\text { Cosma and Saint Damiano } \\
\text { [28]. }\end{array}$ & $\begin{array}{l}\text { Church of Madonna del } \\
\text { Pettoruto (Calabria) [97]. Church } \\
\text { of Saint Libera (Veneto) [25]. }\end{array}$ & $\begin{array}{l}\text { Holy Water [55]. } \\
\text { Blessed Oil [46]. }\end{array}$ & & $\begin{array}{l}\text { Use Madonna di Bibano's belt } \\
\text { [46]. }\end{array}$ \\
\hline Children Diseases & & & & & $\begin{array}{l}\text { Put next to the bed the stick of } \\
\text { San Francesco di Paola or the } \\
\text { hand of Madonna della } \\
\text { Consolazione's statue [98]. }\end{array}$ \\
\hline Incurable Diseases & $\begin{array}{l}\text { Saint Espedito [29]. Saint } \\
\text { Joseph [25, 31]. Saint Rita } \\
\text { [29]. }\end{array}$ & & & & \\
\hline Pains & & $\begin{array}{l}\text { Crypt of Saint Venanzo (Marche) } \\
\text { where the sick put their } \\
\text { foreheads on [31]. }\end{array}$ & & & \\
\hline
\end{tabular}


Table 2 Contact, signs, formulas and rituals used on certain days of the year to cure disease

\section{Diseases \\ Certain infectious and}

parasitic diseases

Tuberculosis Adenitis

Anthrax

Erysipelas

Scrape and eat the dust of the church walls or wearing the ground collected close to the Chapel of Madonna del Latte (Abruzzo) $[24,30]$.

Hang around the neck a small sack containing different objects

including blessed olive leaves [24].

$$
\text { Signs }
$$

Formulas

Days

Making crosses using a holy gold

ring [30].

Reciting a formula related to Holy Trinity [37].

Making a cross using a metal with the symbol of Solomon engraved on it; making crosses with a gold object, a wedding ring or a silver object $[24,30,99]$. Drawing the sign of Solomon on the thumb [36]. Making three crosses using the fingers [89, 100]. Apply on the part a sheet of paper with a drawing of a circle, four crosses and holy words; applying on the body tracing paper on which is drawned a cross [28].

Making crosses on the stomach $[28,49,62]$
Reciting a formula rubbing a wool cloth or the feather of a black hen dipped in oil on the part; reciting a formula wetting the part with breast milk and touching it with the point of a scythe; reciting a formula making a cross with a silver coin [38]. Reciting a formula applying leaves of elder in the form of a cross [90]. Reciting a formula related to Mary, God, Saint Nunziata, Saint Croce, Saint Nicola; reciting a formula rubbing a silver coin on the part [55]. Making crosses with the left thumb reciting a formula [89]. Reciting a formula miming nine crosses on the body using a knife [24]. Making crosses with a gold object reciting a formula $[32,45,64]$.

Reciting a formula resting the hands on the forehead [38].

Reciting a formula related to Holy Trinity, Mary, Jesus, Saint Cosma, Saint Damiano, Saint Elia, Saint Giobbe, Saint Giuliano, Saint Biagio, Saint Martino, Saint Rosalia, Saint Oronzo, Saint John and Holy Week $[24,28,40,52,55,89,90,98$,

101-104]. Reciting a formula shaking the child upside down; Reciting a formula making the patient drink barley water and wetting the mouth with honey; reciting a formula making three times the sign of the cross and massaging with ointment [90]. Reciting a formula massaging the lower stomach [38, 93]. Draw crosses on the umbilicus reciting formula [56]. Reciting a formula
Using coal found during the day of Saint Lorenzo [65]. Drinking an egg at Easter that was produced on Good Friday [30].

Rolling the child on the ground on Easter Saturday [31]. Using garlic or wild mint picked on the day of Saint John $[23,30$, 45]. Using gentian picked on the day of Holy Cross [60]. 


\section{Table 2 Contact, signs, formulas and rituals used on certain days of the year to cure disease (Continued)}

Herpes

Leprosy

Malaria

Drink water of the church of San Mercurio (Sicily); apply a

handkerchief that was kept open

during the prayer of the Salvatore [28].

Mumps

Pediculosis

Rabies

Carrying a splinter from the door of the church of San Vito Lo Capo (Sicily) [28].
Applying on the part, nine times, four little leaves of blackberry bush in the form of the cross [100].

Making three crosses using an axe $[24,37]$. Miming the sign of cross on the spleen [30, 37]. Apply on the spleen two strips of blu paper in the form of a cross; apply the stalks the flant of plant called "pastorella" in the form of a cross [24]. Making crosses on the lower stomach [28].

Draw on thepart using a feather the sign of Solomon $[23,24,51,52]$. The sign of Solomon was traced on two hot bricks which are applied to the body [27, 28, 51, 55]. Miming the cross with the thumbs, an axe or using a gold ring $[24,36]$. Writing the initials of holy words [24,37]. The seventh-born of seven sisters The seventh-born of seven sisters made a serious of crosses after putOn the part of the body you make On the part of the body you make three crosses using

Scabies
Reciting a formula related Holy Week and Ascension [28].

Reciting a formula related to Saint Antonio [55].

miming the pulling out of worms

from the stomach [40].

a formula related Saint

Antony [28]. Making the sign of the

cross using a gold ring and reciting

a formula [30].

Reciting a formula related Saint

Margherita [24]. night of Saint John [59].

Drink wine with coal that was found during the day of Saint Lorenzo [28,

65]. Begging for food in three or

nine houses during the Christmas

night $[36,88]$.

Put on the head the dew collected on the day of Saint John [99]. Diving in the sea or rolling naked in the meadows during the night of Sain John $[28,30,58,65,105]$. Diving in the sea or rolling in the meadows during the night of the Ascension

$[28,55,65,86]$
Reciting a formula dragging the tail of a black cat across the mouth [24] gold ring reciting a formula [106]. 
Trombiculosis

Tuberculosis

Warts

Enter through the church door in which you've never been [46].

Diseases of the blood and blood-forming organs and certain disorders involving the immune mechanism

Favism

Endocrine, nutritional and metabolic diseases Goitre

Mental and

behavioural disorders

Fear

Drink water in which the medal of Saint Elena and Saint Diego has been immersed [91].

Madness

Diseases of the nervous system

Nervous Ailments

Epilepsy

Headache
Miming with a burning coal the sign of Solomon: Miming a sign of cross with a wedding ring [45].

Reciting a formula applying omentum of calf on the lower stomach and on the back [30].

Miming on the part a cross using a knife [28]. The seventh-born of seven brothers apply on the part two reeds in the form of a cross; burying two wooden stakes in the form of a cross [23].

Sign the sufferer with crosses [95].

a formula related Jesus and Mary [46]. Reciting a formula tieing warts with six strands of straw which are then thrown into a wall [28].

Reciting a formula covering the patient with the smoke of incense [28].

\section{Making a cross with a wedding ring} [30].

Cutting the hair in the form of the cross [64].
Making the cross using the tool used to make woollen balls [37].

Making a cross with the stalk of a plant called "jia petrosa" and put it
Tie a ribbon around the head on the day of Confirmation [30].
Reciting a formula related to God, Mary, Saint Joseph, Jesus, Saint Peter,
John [28].

Rubbing an egg on the part

produced on the Ascension Day [36].

Drink fave beans that have been polverized and cooked on Easter Thursday [95].

Drink an egg produced on Ascension Day [30].

Use lavender or drink the decoction of chamomile collected on the night of Saint John [23, 49, 61].

Use gentian collected on the day of Holy Cross [60].

Put on the head the dew collected on the night of Saint John $[23,24]$. 


\section{Table 2 Contact, signs, formulas and rituals used on certain days of the year to cure disease (Continued)}

\begin{tabular}{|c|c|}
\hline Insomnia & $\begin{array}{l}\text { Drink the water that rises near the } \\
\text { church of Vergine di Santa Maria di } \\
\text { Gesù [28]. }\end{array}$ \\
\hline \multicolumn{2}{|c|}{$\begin{array}{l}\text { Diseases of the eye } \\
\text { and adnexa }\end{array}$} \\
\hline Eye Ailments & $\begin{array}{l}\text { Touch the part with a crystal that } \\
\text { came into contact with a relic of } \\
\text { Saint Lucia [29]. Wash with the water } \\
\text { rises near the Chapel of Saint Lucia } \\
\text { [30]. Touch the part with stones } \\
\text { collected in the grounds close to } \\
\text { the Sanctuary of Santa Maria della } \\
\text { Rocca [28]. }\end{array}$ \\
\hline
\end{tabular}

Catarats

Conjunctivitis

Pterygium on the forehead [38]. Put on the head of the patient a bucket of boiling water making crosses on the forehead [24]. Applying on the nape form of a cross [96].

Making a cross using wedding ring [30]. two blessed olive branches in the
Saint Donato, Saint Silvestro and Reciting a formula putting two black cockerels on the head and on the feet; reciting a formula rubbing the hand on the forehead $[38,101]$. Reciting a formula putting a plate of oil on the head; making three crosses while tightening a handkerchief on the head and reciting a formula; reciting a formula making a cross on the head [28].

Reciting a formula breathing on the eyes while chewing rute [90].

Reciting a formula spitting on the ground [45]. Reciting a formula related to Saint Lucia, Saint Joseph, Jesus and Mary [24, 38, 55, 97]. Reciting a formula applying on the eye a wedding ring or a silver object and making signs of cross on the part [24]. Reciting a formula applying a little bough of fennel on the eye; reciting a formula passing on the reciting a formula passing on the
part the eye of the needle or a gold part the eye
brooch [27]

Reciting a formula making signs of cross [56].

Reciting a formula lowering down eyelid and moving it from right to left [107].

Reciting a formula applying a small branch of fennel or verbain on the eye passing on it a gold ring.

Reciting a formula touching the part with a clove of garlic and making three crosses [28].
Passing over a stream three times on decoction of bettony collected the decoction of bettony collected the night of Saint John; applying the
ashes of the first Wednesday of Lent; ashes of the first Wednesday of Lent; wearing on the head a crown of flowers on the day of Saint John wash using the water of seven 30]. Passing on the forehead a silver coin wetted with chamomille collected on the night of Saint John [62]. Applying lavender collected on [62]. Applying lavender collected on
the night of Saint John; drink an egg the night of Saint John; drink an egg
produced on the Good Friday [23].

Washing using the water of polenta cooked on Easter Saturday [46]. Washing with water on Easter Saturday $[23,36]$.

Using water, which has had roses left in it during the night of Ascension [42].

Wetting the eye during Easter

Miming a cross with a white strand passed through a needle [64]. The sign of the cross must be done by 
Table 2 Contact, signs, formulas and rituals used on certain days of the year to cure disease (Continued)

Diseases of the

circulatory system

Epistaxis

Gangrene

Hemorrhages

Hemorrhoids

Spread the grease of a bell [30].

Diseases of the

respiratory system

Asthma

Cold

Hiccup

Pleurisy

Pneumonia

Rhinitis

the last of seven children [99]. A

twin must make with the tongue the

sign of the cross on the eye [91].

Miming signs of crosses [100].

Putting two wooden stakes on the nape in the form of the cross [46,

105]. Sign on the foret

05]. Sign on the forehead the cross

using blood from a nosebleed [30].

Putting two stalks in the form of th

cross on the head or nape [23, 30,

$32,36,42,45]$. Sign with a wedding

ring the cross on the head [32].

Putting three pieces of straw and

three matches in the form of the

crosses on the forehead $[28,99]$.

With the stems of horsetail make a

cross on the head [60]. Draw three

crosses, one on the forehead and

two on the cheeks [23].

Sign the part reciting three Ave

Maria [94].

Reciting a formula related to God

and Jesus [24]

$\sqrt{2}+n^{2}$


Table 2 Contact, signs, formulas and rituals used on certain days of the year to cure disease (Continued)

\section{Tonsillitis}

Diseases of the

digestive system

Gingivitis

Hepatitis

Hernia

pread on the part the grease of a bell [36].

Glandular

Inflammations

Meteorism

Swelling Mouth

Ranula

Stomachache

Rubbing oil taken from a votive lamp $[30,31,46]$. Putting on the part the key of the door of Cathedral [97].

Toothache

Attach and ring a bell using the teeth $[30,38]$.

Rubbing oil taken from a votive

lamp $[28,30]$.
The sign of Solomon was traced on

heated tile that was applied

leaving the sign on the part [108].

Making crosses with a wedding

ring [30]

Drink for seven days an egg after drawing a sign of the cross inside with a coin [37].

Reciting a formula related to Sain Costantino [28].

Use the water left in the open air

during the Ascension night [32]

On Annunciation or Easter Saturday or Saint John or Holy Cross passing three times the child across a split tree or in a circle created by a

branch split in two for the occasion

$[37,40,55,63-66]$.

Reciting a formula rubbing oil on the lower stomach [28]. Reciting formula related to Saint Cosma,

Saint Damiano, Saint Lorenzo,

Saint Apollonia and Saint Leonardo [24, 28].

Reciting a formula rubbing a key under the tongue [24].

Reciting a formula putting ash under the tongue [28].

Making cross with the thumb [31].

Reciting a formula related to God, Holy Trinity, Mary, Jesus, Saint Peter, Saint Biagio, Saint Giobbe, Saint

Martino, Saint Rocco and Holy Week

$[28,30,55,64,93,97,98,103,109]$. Reciting a formula rubbing warm oil on the part $[24,55,109]$. Reciting a formula healer walking on the sufferer [28]

Making cross with a wedding ring [30]. tooth with the root of scotch
Applying on the part a coal found during the day of Saint Lorenzo [49]. Rolling on the ground the day of

Easter Saturday [23].

Eat three seeds of grapes during the day of Saint John [36].
Reciting a formula touching the reciting a formula touching the tooth with a stalk of wheat [93]. Reciting a formula related to Holy Trinity, Mary, Jesus, Saint Peter and Saint Leonardo [38, 93]. Applying mush of parsley, oak and acacia reciting a formula [36] 
Table 2 Contact, signs, formulas and rituals used on certain days of the year to cure disease (Continued)

Diseases of the skin

and subcutaneous

tissue

Boils

Acne

Alopecia

Calluses

Chaps

Milk Crust

Skin Diseases

Skin Eruptions

Hyperhidrosis

Impetigo

Lupus

Maculas

Wrinkles

Diseases of the

musculoskeletal system

and connective tissue

Arthritis

Rubbing oil taken from a votive

$$
\text { lamp [28, 30]. }
$$

Drawing on the part the sign of Solomon $[30,47]$.

Miming three signs of crosses on the part $[31,101]$
Reciting a formula bandaging the part with a warm cloth [90].

Reciting a formula related Holy Trinity and Mary [24].

Miming three crosses on the part reciting a formula [28].

Wetting with seawater collected on the night of Saint John [96.

Applying the dew collected on the night of Saint John [23, 24, 30, 36].

Stepping barefoot onion on plants during the day of Saint John [30].

Applying vinegar used during Christmas dinner [36].

Wetting the head during Christmas night [58]. Put on the head the dew collected on the night of Saint John [45].

Rolling in the meadows during the night of Saint John [31]. Diving in the sea during Christmas night or Ascension night [28, 55].

Applying the dew collected on the night of Saint John $[23,96]$.

Applying the dew collected on the night of Saint John [45]. Rubbing an egg produced on the Ascension day on the part [36].

Applying the dew collected on the night of Saint John [23].

Applying capon fat used during the Christmas dinner [31]. Use a stone collected on the night of Sain John [96]. 
Table 2 Contact, signs, formulas and rituals used on certain days of the year to cure disease (Continued)

\section{Dislocations}

Gout

Sciatica

Sprains

Diseases of the

genitourinary system

Uterus Ailments

Renal Colics

Rubbing a stone placed close to the church of Saint Getullio on the back rubbing the sides on the columns of a church [24]. Rubbing the sides on the walls of a church [38]. Keep in the hand nine walnuts that come from a crib [28].

Impotence

Infertility

To regularize

Menstruations

Metrorrhagia

Wombache

Pregnancy, childbirth and the puerperium

Abortus

Making crosses on the part [30 $100,106]$.

Drawing on the part the sign of Solomon [47].

Making with oil three signs of crosses on the part [31].

Making crosses rubbing oil on the part [28].

Making three crosses touching with feet the loins of the sufferer [30]

Reciting a formula while healer sitting astride sufferer [24, 32, 94, 96]. Reciting a formula related to Beato Salvatore [98].

Put on the lower stomach small pieces of straw in the form of a cross or drawing crosses with ink or soot [23].
Reciting a formula bandaging the part [89].

Reciting a formula related Jesus, Mary and all the Saints [47].

Reciting a formula related to Mary, Saint Sisto and Saint Silvestro [96]. Reciting a formula rubbing hard on the part [24].

Reciting a formula rubbing oil on the part [28]. Reciting a formula related to God, Holy Trinity, Mary, Saint Joseph and Saint John [24].

Use the decoction of chamomile collected on the night of Saint John [30]. Use gentian collected on the day of Holy Cross [60].

Urinating on a plant of rosemary during the night of Saint John [23].

Applying the decoction of various

herbs collected on the night of Saint John [30].

Use lavender collected on the night of Saint John [23].

Reciting a formula related to Saint Marta [23].

Reciting a formula related to the Holy Trinity and Saint Cipriano

$[89,93]$.

Reciting a formula related to God [98]. 
Table 2 Contact, signs, formulas and rituals used on certain days of the year to cure disease (Continued)

\begin{tabular}{ll}
\hline To favour Birth & Attach and ring a bell using the \\
& teeth [52]. Apply on the head a \\
& handkerchief that was kept open \\
& upon a Mary's altar [30].
\end{tabular}

Colics of Infants

To eliminate Maternal

Milk

To favour the

secretion of Maternal

\section{Injury, poisoning and \\ certain other \\ consequences of \\ external causes}

Insect Bites

Venomous Bites

Foreign Body in Eyes

Foreign Bodies in

Respiratory Tracts

Burns

Contusions

Fractures

Wounds

Drop on the part oil drips previously dropped on a blessed olive leaf [99].
Eat the left-overs from table of Capuchins $[24,32]$. Wearing the ground collected close to the Chapel of Madonna del Latte [30]. Eat the leftwearing chick-peas donated by a priest; drink the water that rises near the churchs of Saint Scolastica, Saint Agata or near the monastery of Franciscans; [24].

Put on the breasts leaves of parsley

in the form of a cross [99].

Miming three crosses on the shoulders [28].

citing a formula lighting a candle during Candlemas day [38]

Reciting a formula related to Jesus, Saint Cosma and Saint Damiano [28].

Reciting a formula related to Saint Agata [24].

Making crosses with the thumb [110].

Miming a sign of cross using a wedding ring or a piece of a plate $[28,46]$.

Miming three crosses on the part [38].
Reciting a formula rubbing a cloth dipped in oil and soot on the part $[28,38]$. Reciting a formula making with the thumb a sign of cross [89]. Reciting a formula attaching a strand
Reciting a formula applying a knife on the part [28].

Reciting a formula related to God.

Reciting a formula closing the eyes [105].

Reciting a formula drawing a circle on the part [24]. Reciting a formula related to Mary [24,55].
Eat a piece of bread used during Christmas lunch or offered during the day of Saint Biagio [30]

Applying butter, pork fat, oil or remains of candle used during Christmas dinner [36].

Applying the sticks of cork oak collected on the day of Saint John [111].

Applying butter, oil or pork fat used during Christmas dinner [36]. Use the dew or the lavender collected on the night of Saint John $[23,25]$. Rubbing elm's oil or Saint John's 
Table 2 Contact, signs, formulas and rituals used on certain days of the year to cure disease (Continued)

on the part [109]. Reciting a formula

External causes of

morbidity and

mortality

Falls

Miscellanea

All Diseases

Rubbing oil taken from a votive

lamp [24, 32].

Children Diseases

Rubbing oil taken from a votive

lamp [46]. related to Jesus, Mary and Saint

Lazzaro [24].

wort's oil collected on the day of Saint John $[28,29]$. Using oil, which, has had lizards and scorpions left in it and captured during the

Ascension day [99]. Use blackberry

bush's oil collected on the day of

Ascension day [95].

Drink an egg during Ascension day [30].

Reciting a formula related to Jesus and Mary [90].

Use water collected from a public fountain during the Christmas night [97]. Diving in the sea during

Ascension day $[55,92]$. Using water which, has had roses left in it during the night of Ascension [55].

Use garlic collected on the day of Saint John [59]. 
toothache [23, 25, 27, 28, 30-33]; Saint Agata who had her breasts cut off, is prayed to by breast feeding mothers [23-25, 27, 28, 30], and so on. Another reason for the choice of the Saint was indicated by its name. The linguistic meaning of the name between the Saint and the disease, according to Italian folklore, was sufficient motivation to ask a Saint to heal a specific disease [34]. For example, Saint Liberata, whose name derives from Latin word "libero", meaning to release, was invoked for the liberation from all diseases [29]. Similarly, Saint Lucia, from the Latin word "Lux", meaning light, was considered the protector of the sufferers of eye diseases [25, 27-32, 35-37]. The special healing power was, after all, attributed based on what the Saint did during its life: Saint Biagio was invoked to heal throat ailments [25, 28-32] because he saved a child from suffocation; Saint Anna and Mary were invoked by pregnant mothers because they represent Motherhood [25, 29-32, 38] (Saint Anna being the mother of Mary and Mary being the mother of Jesus); while, Saint Cosma and Saint Damiano, that in their life were doctors, were invoked to heal all diseases [28].

\section{Pilgrimages}

Making a journey to a sacred place was, and still is, a widely used practice in Buddhism, Christianity, Hinduism and Islam. In the Catholic tradition it was thought the disease was a temporal punishment and that healing came from the remission of sin. The pilgrimage was undertaken to obtain plenary indulgence to resolve, hence, more the moral problem than the medical problem [39]. Moreover, very often, the place of pilgrimage was chosen based on "thaumaturgic capacity" of the saint to cure a particular disease, and for this reason, in Italy there was a true network of sacred sites with the function of a "surgery". The practices put in action when the person arrived at the sacred sites weren't only religious rites (Table 1). Very often the sufferers used a rite of passage: to cure epilepsy they undressed from their old clothes that they left in the church and wore new ones [24]. Another rite was to weigh the sufferer and offer to the saint the identical weight in grain [24]. To heal Insanity, Hernia and Rabies, the pilgrim had to exit from another door and not the one they entered in $[28,40]$.

\section{Holy Water and Blessed Oil}

Holy Water and Blessed Oil are among the Sacramentals "instituted for the sanctification of certain ministries of the Church, certain states of life, a great variety of circumstances in Christian life, and the use of many things helpful to man" [41]. In Table 1 are described the remedies used by Italian folk medicine that considered Holy Water and Blessed Oil to be potent symbols of rebirth, capable of eliminating sins and driving away evil, often indicated as the cause of the illness. Humectations of Holy Water were made to cure Stomatitis and Eye Ailments [28, 30, 38, 42, 43]. Holy Water was drunk to treat Rabies and was considered useful to treat Hyperhidrosis submerging the hands in the stoup [28]. Finally, Blessed Oil was wiped to heal Sore Throats and to cure Arthritis [30, 37].

\section{Blessings}

Even today, it is very common in the Roman Catholic Ritual to use various types of Blessings. Priests bless the sick, everyday objects, food, animals, homes, public buildings, etc. [44]. Italian folk medicine used blessings as therapy to heal many diseases (Table 1). For example, to bless the sick or the part of the body concerned, to cure Erysipelas, Typhus and to favour birth without complications $[23,32,45]$; eating blessed food was used to favour the secretion of maternal milk [30] and, even, to heal Sore Throats you needed to wear a blessed shirt [46].

\section{Religious objects}

A large range of objects, associated with healing saints, were used in Italian folk medicine: sacred images, Saint Vito's rope, Saint Francesco's stick, etc. Other objects, however, even if they weren't associated with the saints, were used in its name in to fight certain illnesses (Table 1). The key of Saint Valentine or those of Saint Donato were put in the hand of an epileptic during paroxysm [23, 46, 47] giving the healing power of iron, which was capable of driving away the evil spirits in the sufferer [48]. Another example is the use of the Rose of Jericho, that in Italian folklore was known as the Rose of Mary or Saint Anna [27, 45, 47, 49]. This plant, common in North Africa, Asia Minor, the Middle East, represents the vital cycle that concludes at the start of the dry season, when it folds its branches in a compact spherical mass. In reality, when the rains start the plant rehydrates, the branches open and the growing cycle begins. This characteristic was interpreted by folklore as a magical event in as much as, once watered, was put near the expectant mother with the belief that it would open its branches this would in turn open the uterus ensuring a healthy and incident free birth [50].

\section{Contact}

Italian folk medicine recognised the power of thaumaturgic and all that came from contact with a sacred place or object (Table 2). For example, oil was used in a votive lamp to treat Stomachache [30]; you dragged your sides along the walls of a church to heal Kidney pains [38]; you carried the glass of a church lamp to avoid Abortion [37]; spread the grease of a church bell to cure Haemorrhoids [30]; for Toothache you needed to attach and ring a church bell using your teeth [30,38]; you carried with 
you earth collected from a sacred place to combat a Fever [30].

\section{Signs}

Marking on the body of a sick person, was common practice for several illnesses and was done in different ways, sometimes praying or saying mysterious words (Table 2). For example, to heal Mumps, it was drawn directly on the affected part of the body, a cross or the sign of Solomon [23, 24, 51, 52], a symbol with its roots in paganism and in magical symbolism [53], or to write sacred words, for example Jesus, Joseph and Mary [24]. To heal malaria the sign of the cross was mimed on the spleen using the wedding ring or holding a knife or an axe in a clenched fist $[28,30]$; to cure Headaches or Epistaxis, the signs were reproduced on the sufferer using a cross made of the stems of certain plants $[23,30,32,36$, $38,42,45]$; finally, you needed to trace three times using oil, the sign of the cross into the affected part of the body to treat Sciatica [31].

\section{Formulas}

Using the recital of certain formulas, often accompanied with massage, symbols on the body, the use of ritualistic objects and medicinal herbs or animal parts, religious folklore puts into use a ritual useful for healing (Table 2). The formulas that De Martino defined "historiole" [54] presented a largely homogenous form. The patient began by reciting an episode in the Saint or Jesus or Mary's life, and finished by begging the disease to disappear.

Santa Lucia 'n campa stavia, oru tagliava e argientu facia. Passa Gesù, Giuseppe e Maria, Chi hadi Lucia, chi lacrime jia? Và allu miu ortu e trovi zìpari e finocchi; $\mathrm{Cu}$ li lie piedi li chiantai, $\mathrm{Cu}$ le mie mani li zappuliai, Esci purvera, esci purata, Esci vena 'nsanguinentata [55] (Saint Lucy was in a field, cutting gold and making silver. Jesus, Saint Joseph and Mary passed and asked her? What's the matter? Why are you crying? Go to my orchard and find figs and fennels; I planted them with my feet, and I hoed them with my hands. Go away dust, go away puss, go away bleeding vein).

In other formulas, more simply the healer invited the illness to leave the sufferer in the name of God, Jesus, Mary, the Holy Spirit or in the name of a saint or even in the name of Christmas or Holy Week.

Sciuvidia santu/Venerdia santu/Sabatu santu/Pasca santa/Via li vermi/de sta panza [56] (Holy Thursday, Good Friday, Easter Saturday, Easter Sunday. Go away worms from this stomach).

\section{Religious calendar}

In Table 2, are described the remedies of Italian folk medicine used on certain days of the year dedicated to important Catholic festivals, like Christmas (25th of December), the day of Annunciation (25th of March), Easter (the Sunday following the first full moon after spring equinox), Ascension (40 days after Easter), Pentecost (50 days after Easter), the day of Holy Cross (celebrated on 3rd of May before the reform of the religious calendar in 1970), the day of Saint John the Baptist (24th of June) and that of Saint Lawrence (10th of August). The theory of Frazer suggested that Christianism has integrated, inside its rites many pagan rites that are celebrated based on agricultural and natural cycles. For example, Christmas and the feast day of the birth of Saint John the Baptist can be traced back to pagan festivals that celebrated the time of year in which the daylight began to progressively lengthen (winter solstice) and the period of maximum daylight (summer solstice) that represent the myth of death-rebirth of vegetation making nature fertile (man included) [57]. In this context we can interpret therapies used by folklore medicine for healing various diseases. During Christmas night, for example, people bathed in the sea to fight Skin diseases [55], water taken from public fountains was used to treat Milk Crust in children [58], spreading oil, fat or butter to heal Wounds, Bruises and Arthritis [31, 36]. Similarly during the night of Saint John, sufferers of Leprosy rolled in fields [59], collecting dew to heal Alopecia [23, $24,30,36]$, diving in the sea to cure Scabies [28], medicinal herbs were picked [23, 28, 30, 45, 49, 59-62] because, it was thought their healing virtues grew in these occasions. Finally, a remedy practiced on Annunciation, Easter Saturday, Saint John the Baptist, the Holy Cross to heal hernias in children, consisted of passing the sufferer three times across a split tree or in a circle created by a branch split in two for the occasion [37, 40, 55, 63-66].

\section{Discussion}

Disease represents for mankind one of the most critical and devastating moments in the human life cycle because of its turbulent effect on the individual, giving the sufferer a sense of helplessness, it limits the autonomy and puts in crisis the equilibrium of the whole family group of the sufferer [67].

Previous studies conducted on Italian folk medicine, between the end of XIX and the middle of XX century, to heal malaria [68] and epilepsy [48] have shown, together with a vast body of remedies based on the use of plants and animal parts, a large repertoire of religious practices. The sick entrusted God with prayers or acts of devotion, with the conviction that only God would be able to provide recovery from the above mentioned diseases. In the present work the enormous amount of data has made it necessary to interpret, from the key anthropological point of view in relatively few cases. However, they are considered by the authors to be sufficiently demonstrative of all the corpus of religious remedies used in Italian folk medicine to cure disease shown in Table 1 and Table 2. 
To face the moment of crisis, tools were used to identify and symbolize the disease and to cure using coherent therapies based on their own cultural background, which means a set of views, beliefs, values, and attitudes towards life that is transmitted from generation to generation and may be expressed through customs, etiquette, taboos, or rituals [69].

This has determined inside Italian folk tradition a process of syncretism that has brought with it, other than the use of religious remedies that are a part of the landscape of the Catholic Church (begging for the intervention of the thaumaturgic saint, the use of Holy Water and Blessed Oil, pilgrimages and the use of sacred objects), also the use of practices that have come out of a process of contamination between the Catholic religion, the magic world and pre-Christian rituals. The rituals, for example, that call for the use of iron or metallic objects were put into use with the aim of driving away evil, considered as the cause of the disease; hence, passing a child, suffering of hernia, through a split in a tree, or abandoning in church the old clothes and wearing new ones to cure epilepsy, were considered symbols of re-birth which is the abandoning of the old life and acquisition of a new one, free from suffering.

It would be wrong to categorise religious remedies brought to light in this work in the group of the past superstitions. Religious remedies, used in Italian folk medicine between the 19th and the 20th century, form the historical bases of what many people currently perform in Italy, that is turning to prayer or participation in pilgrimages as well as the official medical system of diagnosis and treatment.

An example of engagement with healing prayer are Pentecostal churches [70] that have more of 300,000 Italian devotees [71]. Another excellent example is the cult of Padre Pio whose sanctuary in San Giovanni Rotondo receives million of pilgrims every year [72]. "Devotees of Padre Pio, for his Christ suffering and supernatural visions and stigmata, view the saint as an intimate and invisible friend. So the pilgrimage elicits a distinctive sense of "fellow-feeling", a sympathetic recognition of another social organism's humanity, a sense of unity in diversity. Pilgrimage fosters not only a religious experience with a liminal destination, but what Turner calls communitas. Communitas is more than merely sense of "community" - a term which itself is imbued with a geographical sense of common living within a social structure. Rather, occurring in the liminal phase of rituals wherein individuated statuses are suspended as individuals pass from one state to another, or from one structure to another, communitas is social anti-structure, a trascendence of social statuses that serve to order a social community" [73].

On the same basis, part of the Italian population still turns to healers, uses amulets, follows rituals and recites formulas and oaths to treat, for example, "malocchio" (evil eye) that is regarded for mostly physical diseases [15, 16, 74-76]. Moreover, "malocchio" ranks as one of the most searched words in Google Italia in 2014 [77].

Finally, many remedies of Italian folk medicine described in this work (i.e. candles, incense, minerals and Rose of Jerico) are also used by New Agers [50, 78].

There is nothing surprising about it, Garelli [14] in his work highlights that $43 \%$ of Italian catholic population adhere to Catholicism for traditional and cultural reasons or they share its fundamental ideas even if they interpret them in autonomous and subjective way.

The question is if these remedies have had and continue to have a positive impact in facing disease and also if they have some importance from the anthropological point of view. Already, De Martino recognized magical and religious remedies of folk tradition of Southern Italy a protective-psychological value [54]. The authors believe that the vast corpus of religious remedies, highlighted in the present work, can be found inside current coping strategies that patients and relatives adopt to affront the crisis that has hit their personal identity and integrity, kick-starting inner energy that can contribute to the healing process. According to Droogers [79] syncretism seems to occur in an unreflective manner, as a "natural" or better cultural process. As a consequence, people who mix varied religious elements may not do so intentionally and would not necessarily defend or propagate their blended religious practices. Thus, syncretism often serves as a practical mean of solving existential problems.

The spiritual need that the sick shows adopting religious and magical practices, represents a symbolic framework, that works as a filter, mediates, containing the pain that constantly fills everyone's life in remote ages even in the third millennium [80]. Considering these points, there is the need to add some other explanations more linked to the organic human functions. Many studies report that a silent prayer, meditation or the participation in religious celebration activate the parasympathetic function of the brain, suggesting moreover that these practices can lead to a more active immune response to the pathogenic agents $[81,82]$.

The theory of PNEI that all our feelings are experienced and psycho-neuro-endocrino-immunologically expressed in the body has been proposed since the late 20th century. Soma and psyche are two aspects of human life and there is a constant interplay between the two [83].

A more detailed analysis on the possible explanation of the functional meaning of suggestion evoked the activation of the limbic-hypotalamic axes, defined as "the locus of information transduction from the neural encoding of the languages of the mind (thoughts, sensations) into the messenger molecules" [84]. It is well known in fact that this system represents a functional connection 
between the sympathetic control centres (cardiovascular, respiratory, etc.) and the entire endocrine system, with subsequent ability to also influence immune activity [85]. On this ground it is reasonable to hypothesize that the satisfaction of spiritual needs in a stressful condition might support the recovery from individual sufferance via the releasing of neuromodulators (i.e. Interleukins) and hormones (Adreno Corticotropic Hormon, Prolactin, etc.) that have been proved to help in the healing process [22].

\section{Conclusions}

The studies concerning the impact of secular forms of spirituality regarding disease, are important currently because they offer to health-workers a key to understanding, from an anthropological and a psychological point of view, which could help to understand, interpret and satisfy the growing need for spirituality the sufferer, deeply rooted in their culture and traditions.

Research such as this, moreover, can give important information about which model of therapeutic belief impacts on modern society and which elements could be integrated into a holistic approach to disease that considers the patients not just as "having symptoms", as a clinical case but also as an individual that carries a baggage of needs, suffering, hopes and desires.

\section{Competing interests}

The authors declare that they have no competing interests.

\section{Authors' contributions}

GT designed the research study and wrote early drafts of the manuscript. NR improved the manuscript from psychological point of view. OG collected the data. All authors read and approved the final manuscript.

\section{Acknowledgements}

The authors wish to thank Dr. Maria Liguori for useful suggestions and for the critical review of the manuscript.

Received: 24 November 2014 Accepted: 14 May 2015

Published online: 06 June 2015

\section{References}

1. Torosian MH, Biddle VR. Spirituality and Healing. Semin Oncol. 2005;32:232-6.

2. Karekla M, Costantinou M. Religious coping and cancer: proposing an acceptance and commitment therapy approach. Cognitive and Behavioural Practice. 2010;17:371-81.

3. Dein $\mathrm{S}$, Cook CCH, Koenig H. Religion, spirituality, and mental health current controversies and future directions. J Nerv Ment Dis. 2012;200:852-5.

4. Koffman J, Morgan M, Edmonds P, Speck P, Higginson J.I know he controls cancer': the meanings of religion among Black Caribbean and White British patients with advanced cancer. Soc Sci Med. 2008:67:780-9.

5. Bonelli RM, Koenig HG. Mental disorders and spirituality 1990 to 2000: A systematic evidence-based review. J Relig Health. 2013;2:657-73.

6. Stewart WC, Adams MP, Stewart JA, Nelson LA. Review of clinical medicine and religious practice. J Relig Health. 2013;52:91-106.

7. Burkhart L, Hogan N. An experiental theory of spiritual care in nursing practice. Qual Health Res. 2008;7:928-38.

8. Geertz C. The interpretation of cultures New York: Basic Books. 1972.

9. Eliade M. Patterns in comparative religion. New York: Sheed \& Ward; 1958.

10. Tarakeshwar N, Stanton J, Pargament KI. Religion. An overlooked dimension in cross-cultural psychology. J Cross-Cult Psychol. 2003;34:377-94.
11. Kleinman A, Benson P. Anthropology in the clinic: the problem of cultural competency and how to fix it. Plos Medicine. 2006;3:1673-6.

12. Landrine H, Hope E, Klonoff A. Culture and health-related schemas: a review and proposal for interdisciplinary integration. Health Psychol. 1992;11:267-76.

13. Koegel P. Through a different lens: an anthropological perspective on the homeless mentally ill. Cult Med Psychiatry. 1992;16:1-22.

14. Garelli F. Flexible catholicism, religion and the church: the italian case. Religions. 2013;4:1-13.

15. Seppilli T. La medicina popolare in Italia: avvio a una nuova fase della ricerca e del dibattito. La Ricerca Folklorica. 1983;8:3-6.

16. Quave $\mathrm{CL}$, Pieroni A. Ritual healing in Arbëreshë Albanian and Italian communities of Lucania, Southern Italy. J Folk Res. 2005;42:57-97.

17. Eurispes. Rapporto Italia 2010. Roma: Datanews; 2010.

18. Cirese AM. Manuale di letteratura italiana. Storia per generi e problemi. Dall'unità d'Italia alla fine del novecento. In: Brioschi F, Di Girolamo C, editors. Lo studio delle tradizioni popolari. IVth ed. Torino: Bollati Boringhieri; 1996. p. 921-41.

19. ISTAT, ISTAT. L'Italia in 150 anni. Sommario di statistiche storiche 1861-2010 Istituto Nazionale di Statistica. Roma: ISTAT; 2011.

20. Sapelli G. Storia dell'economia italiana. L'età contemporanea un paese nuovo. In: Romano R, editor. Dalla periferia all'integrazione europea. Illth ed. Torino: Giulio Einaudi Editore; 1991. p. 59-141.

21. International statistical classification of diseases and related health problems 10th revision http://apps.who.int/classifications/icd10/browse/2010/en.

22. Muzur A, Skrobonja A, Rotschild V. Skrobonja Ajr, Saints-protectors from Snake Bite: A Short Overview and a Tentative Analysis. J Relig Health. 2005:44:31-8.

23. Ostermann V. La vita in Friuli, Usi, costumi, credenze, pregiudizi e superstizioni popolari. Udine: Tipografia del Bianco Editore; 1894.

24. Finamore G. Tradizioni popolari abruzzesi Torino. Palermo: Carlo Clausen Editore; 1894.

25. Mazzucchi P. Leggende, pregiudizi e superstizioni del volgo nell'Alto Polesine. Archivio per l'Antropologia e la Etnologia. 1888;XVIII:259-76.

26. Amorosa BG. Riccia nella storia e nel Folklore Casalbordino: Tipografia Nicole De Arcangelis. 1903.

27. Adriano A. Carmi Tradizioni Pregiudizi nella medicina popolare. Calabrese Cosenza: Tipografia Pranno; 1932.

28. Pitrè G. Medicina popolare siciliana Torino. Palermo: Carlo Clausen Editore; 1896.

29. Sani E. Ricette popolari e pratiche superstiziose in Val d'Enza Reggio Emilia: Tipografia Moderna U. Costi. 1942.

30. Zanetti Z. La medicina delle nostre donne. Città di Castello: Lapiti Tipografo Editore; 1892.

31. Eustacchi-Nardi AM. Contributo allo studio delle Tradizioni Popolari Marchigiane. Firenze: Leo S. Olschki Editore; 1958.

32. Zanazzo L. Usi, Costumi e Pregiudizi del popolo di Roma. Torino: Società Tipografico-Editrice Nazionale; 1908.

33. Pedrotti G, Bertoldi V. Nomi dialettali delle piante indigene del Trentino e della Ladinia Dolomitica Trento. Trento: Tipografia della Casa Editrice G. B. Monauni; 1930.

34. Skrobonja A, Muzur A, Culina T. The cult of St. Lucia, patroness of the eyes: some examples from Croatian ethnomedical tradition. Int Ophthalmol. 2004;25:37-41

35. Sembianti P. Superstizione nella medicina popolare trentina, Atti del III Congresso Nazionale di Arti e Tradizioni Popolari. Roma: Edizione dell'O.N.D; 1936. p. 268-77.

36. Riccardi P. Pregiudizi e superstizioni del popolo modenese. In: Archivio per I'Antropologia e l'Etnologia 1890, XX: 2-75. [26] B. G. Amorosa, Riccia nella storia e nel Folklore. Casalbordino (Ch), Italia: Tipografia Nicole De Arcangelis; 1903

37. Pasquarelli G. Medicina magia e classi sociali nella Basilicata degli anni venti. Scritti di un medico antropologo cured by Bronzini GB. Galatina: Congedo Editore; 1987.

38. De Nino A. Usi e Costumi abruzzesi Firenze: Tipografia G. Barbera. 1891.

39. Turner V, Turner E. Image and Pilgrimage in Christian Culture.Anthropological perspectives. New York: Columbia University Press; 1978.

40. Karusio A. Pregiudizi popolari Putignanesi (Bari). Archivio per l'Antropologia e la Etnologia. 1887;XVII:311-32.

41. I sette Sacramenti della Chiesa http://www.vatican.va/archive/catechism_it/ p2s2c4a1_it.htm. 
42. Amalfi G. Tradizioni ed usi nella penisola sorrentina. Palermo: Carlo Clausen Editore; 1890.

43. Pinoli G. Medicina popolare nel canavese. Archivio per lo studio delle tradizioni popolari. 1885;IV:79--84.

44. Conferenza Episcopale Italiana. Benedizionale completo Città del Vaticano: Libreria Editrice Vaticana. 1993.

45. Bernoni DG. Tradizioni popolari veneziane. Venezia: Filippi Editor; 1878.

46. Bastanzi G. Superstizioni religiose nelle provincie di Treviso e Belluno. Archivio per l'Antropologia e la Etnologia. 1887;XVII:271-310.

47. Marzolo F. I pregiudizi in medicina. Milano: Edoardo Sonzogno Editore; 1879.

48. Tagarelli G, Tagarelli A, Liguori M, Piro A. Treating epilepsy in Italy between XIX and XX century. J Ethnopharmacol. 2013;145:608-13.

49. La Sorsa S. Superstizioni, pregiudizi e credenze popolari pugliesi. Lares. 1915;IV:49-67.

50. Gasparroni A. La Rosa di Gerico. Tratti di un'indagine fito-magico-religiosa dalla tradizione ai nuovi contesti. Etnoantropologia. 2007;1:143-9.

51. Pagano L. Natura Economia Storia in Calabria Ristampa anastatica. Cosenza: Edizioni Cronaca di Calabria; 1992.

52. Moffa S. Medicina popolare molisana. Napoli: Tipografia Editrice A. Miccoli; 1937.

53. Wirt E. The seal of Solomon: Some metaphysical and theological implications. J Relig Psych Res. 1982;5:233-8

54. De Martino E. Sud e Magia. Milano: Feltrinelli; 1959.

55. Lombardi-Satriani R. Credenze popolari calabresi. Messina: Peloritana Editrice; 1970.

56. Mancarella A. Superstizioni popolari pugliesi. II folklore italiano. 1930;V:126-51.

57. Frazer JG. The golden bough. A study in magic and religion. New York: The Macmillan company; 1925.

58. Cherubini F. Superstizioni popolari dell'Alto contado milanese. Archivio per lo Studio delle Tradizioni Popolari. 1887; Vl:220---234.

59. Placucci M. Usi e pregiudizi de contadini della Romagna. Archivio per lo studio delle tradizioni popolari. 1884; IIl:525-30.

60. Ferraro G. Botanica popolare in Carpeneto d'Acqui. Archivio per lo studio delle tradizioni popolari. 1885;IV:165-89.

61. Martinengo-Cesaresco E. Fiori di San Giovanni. Archivio per lo studio delle tradizioni popolari. 1890;IX:341-6.

62. Latronico L. La Medicina infantile nelle superstizioni e nelle usanze popolaresche italiane. Modena: Immacolata Concezione; 1935.

63. Corso R. Paralleli Calabro-Lusitani. Calabria Letteraria. 1957;V:5-6.

64. Wagner M. Sopra alcune pratiche magiche in Sardegna. II Folklore Italiano. Archivio trimestrale per la raccolta e lo studio delle tradizioni popolari italiane. 1927;:II-IV:397-411.

65. Romano F, Intorcia M, Politi A. Folklore nel Sannio. Napoli: Edizioni Secolo Nuovo; 1958

66. Calvia G. Animali e piante nella tradizione popolare sarda e specialmente del Logudoro. II Folklore Italiano Archivio trimestrale per la raccolta e lo studio delle tradizioni popolari italiane. 1927;ll:187-206.

67. Rivera A. II mago, il santo, la morte, la festa Forme religiose nella cultura popolare. Bari: Edizioni Dedalo; 1988.

68. Tagarelli G, Tagarelli A, Piro A. Folk medicine used to heal malaria in Calabria. J Ethnobiol Ethnomed. 2010;6:27.

69. Tseng WS, Streltzer J. Cultural Competence in Health Care. New York: Springer; 2008

70. Cartledge MJ. Pentecostal healing as an expression of godly love: an empirical study. Ment Health Relig Cult. 2013;16:501-22

71. Zoccatelli PL. Religions in Italy 2013. The 2013 CESNUR Conference "Changing Religious Movements in a Changing World. Falun (Sweden), 21-24 June 2013. Falun (Sweden): CESNUR; 2013.

72. UNWTO. International Conference on Tourism, Religions and Dialogue of Cultures. Cordoba, Spain, 29-31 October 2007. Madrid: World Tourism Organization; 2008.

73. Di Giovine MA. Passionate movements: emotional and social Dynamics of Padre Pio pilgrims. In: New Directions in Tourism Analysis: Emotion in Motion. Tourism, Affect and Transformation. London: Ashgate Publishing Group; 2012. p. 117-36.

74. Krippner S, Budden A, Gallante R, Bova M. The indigenous healing tradition in Calabria, Italy. International Journal of Transpersonal Studies. 2011;30:48-62.

75. Staro P. Performing Ectasies. Music Dance and Ritual in the Mediterranean. In: Del Giudice L, Van Deusen N, editors. Reconstructing the sense of presence: Tarantula, Arlia and Dance. Ottawa: The Institute of Medieval Music; 2005. p. 55-70.
76. Siniscalchi C. "Uocchie, Maluocchie..." II malocchio nella valle del Lauro (AV). Antrocom online Journal of Antropology. 2013;9:273-82.

77. Https://www.google.it/trends/topcharts accessed 12th May 2015.

78. Berzano L. New Age. Bologna: II Mulino; 1999.

79. Droogers A. Syncretism and fundamentalism: a comparison. Social Compass. 2005;52:463-71.

80. D’Amico R, Cipulli M, Giancristofaro L. Vivere con l'epilessia. Aspetti clinici, psicologici e culturali. Milano: Franco Angeli Editore; 2010.

81. Newberg A, D'Aquili EG, Rause V. Why God won't go away. Brain Science and the biology of belief. New York: Ballantine Books; 2002.

82. Bottaccioli F, Carosella A, Cardone R, Mambelli M, Cermin M, D'Errico MM, et al. Brief training of PsychoNeuroEndocrinolmmunology-Based Meditation (PNEIMED) reduces stress symptom ratings and improves control on salivary cortisol secretion under basal and stimulated conditions. Explore. 2014;10:170-9.

83. Sivik T, Byrne D, Lipsitt DR, Christodoulou CN, Dienstfrey H. Psycho-NeuroEndocrino-Immunology (PNEI). A common language for the whole human body: Proceedings of the 16th World Congress on Psychosomatic Medicine. Goteborg 24-29 August 2001. Int Congr Ser. 2002;1241:1-376.

84. Rossi EL, Cheek DB. Mind-body therapy: Ideodynamic healing in hypnosis. New York: WW. Norton \& Co; 1988

85. Reichlin S. Neuroendocrine-immune interactions. N Engl J Med. 1993;329:1247-8

86. Marzano GB. Usi e costumi di Laureana di Borrello. La Calabria. 1897;10:13-5.

87. Donnarumma V: Cosenza Mariana Cosenza: Tipografia Francesco Chiappetta 1951.

88. De Giacomo G. II popolo di Calabria. Castrovillari: Francesco Patitucci Editore; 1896.

89. Metalli E. Usi e costumi della campagna romana Ristampa anastatica. Sala Bolognese: Arnaldo Forni Editore; 2003.

90. De Gubernatis A. Biblioteca Nazionale delle Tradizioni Popolari Italiane. In: De Gubernatis A, editor. Le Tradizioni Popolari di S. Stefano di Calcinaia. Roma: Forzani e C. Tipografi del Senato; 1894. p. 23-33.

91. Deledda G. Tradizioni popolari di Nuoro. Nuoro: Illisso; 2010.

92. Pignatari FI. San Giovanni e l'Ascensione. La Calabria. 1895;6:1.

93. De Blasio A. Inciarmatori, maghi e streghe di Benevento Napoli: Luigi Pierro Tip. 1900.

94. Pigorini-Beri C. Costumi e superstizioni dell'Appennino Marchigiano. Città di Castello: S. Lapi Tipografo-Editore; 1889.

95. Atzeni V. Spunti di medicina sarda primitiva. Lares. 1959:XXV:420-41.

96. Ginobili G. Bricciche di superstizioni e pregiudizi popolari marchigiani. Macerata: Tipografia San Giuseppe; 1959.

97. Dorsa V. La tradizione greco-latina negli usi e nelle credenze popolari della. Calabria Citeriore Cosenza: Tip. Municipale di F. Principe; 1884.

98. D'Aloi A. Nipiologico del Nicoterese. folklore della Calabria. Rivista di tradizioni popolari. 1957;: :69-82.

99. Nardi GM. La medicina popolare in Toscana. Lares. 1935;Vl:272-82.

100. Pasquali PS. Bricciche del folklore di Valdantena. Lares. 1934;V:303-9.

101. Nitti A. Appunti di folk-lore barese. Malattie e terapia popolare. Apulia. 1912; $\|1\|: 1-17$

102. Scotti P. La medicina popolare in Liguria. In Etnografia e folklore del mare Napoli: L'Arte Tipografica. 1957;675-680

103. D'Amato A. Nuovo contributo al folklore Irpino. II Folklore italiano. 1933; III:141-67.

104. Fucci C. L'arte popolare medica di S. Martino di Valle Caudina. Saggio di Folclore Caudino. 1934;:1:41-5.

105. Balladoro A. Appunti di medicina popolare veronese. Verona: Tipografia G. Franchini; 1907.

106. Vezzani M. Usanze, tradizioni e leggende dell'Appennino Reggiano . Reggio Emilia: Nironi \& Prandi Editori; 1933.

107. Levi-Bianchini M. Superstizioni, pregiudizi e terapia empirica nella razza calabrese. Rivista d'Italia. 1904;VIl:688-96.

108. De Biase Dodaro G. Riti e credenze calabres. Calabria Letteraria. 1955;IIl:61.

109. Tancredi G. Folclore garganico Manfredonia: Armillotta \& Marino Tipografi. 1938.

110. Davegno F. Le superstizioni di Portofino. Archivio per l'Antropologia e la Etnologia. 1888;XVIII:83-90.

111. Corso R. Amuleti italiani con speciale riguardo a quelli calabresi. Calabria Letteraria. 1953;:|:8-9. 